\title{
Time-Dependent Crack Growth Thresholds of Ni-Base Superalloys
}

\begin{abstract}
KWAI S. CHAN
A micromechanical model has been developed for predicting the time-dependent crack growth threshold and its variability by considering oxide formation or cavity formation ahead of an elastic crack subjected to a sustained load at a stress intensity factor, $K$, at elevated temperatures in air. It is demonstrated that stress relaxation associated with a volume-expansion process such as the formation of creep cavities or oxides with a positive transformation strain can induce residual stresses at the tip of the elastic crack. The near-tip residual stresses must be overcome by the external load, thereby instigating a growth threshold, $K_{\mathrm{th}}$, for the onset of time-dependent crack growth. This micromechanical framework provides the basis for developing appropriate predictive models for the time-dependent crack growth thresholds associated with several damage processes, including (1) oxidation-assisted intergranular crack growth, (2) K-controlled creep crack growth along an intergranular path, and (3) stress corrosion cracking. The micromechanical threshold models have been utilized to predict the time-dependent crack growth thresholds of a variety of Ni-base superalloys. The material parameters that contribute to the variability of the time-dependent crack growth thresholds have been identified and related to variations of mixed oxides or creep cavities formed near the crack tip. A size scale effect is also predicted for the transformation toughening phenomenon, which is largest at or below $K_{\text {th }}$ but diminishes at increasing $K$ levels above the threshold. Finally, the micromechanical models are utilized to identify means for suppressing time-dependent crack growth in Ni-base alloys.
\end{abstract}

DOI: $10.1007 / \mathrm{s} 11661-014-2271-8$

(C) The Minerals, Metals \& Materials Society and ASM International 2014

\section{INTRODUCTION}

IN Ni-base superalloys, time-dependent crack growth can occur through several degradation mechanisms, including oxidation ${ }^{[1-9]}$ hot corrosion cracking ${ }^{[10]}$ stress corrosion cracking, ${ }^{[1]}$ and creep cavitation ${ }^{[12-17]}$ at elevated temperatures. In addition, time-dependent crack growth can appear as hold-time effects during dwell fatigue $^{[18-21]}$ where time-dependent and cycle-dependent crack growth occurs concurrently. In most cases, timedependent crack growth, also referred to as sustained load crack growth, environmentally enhanced crack growth, or creep crack growth, can be characterized on the basis of the stress intensity factor, $K$, when the crack-tip damage, creep, or plastic zone is small and constrained within the elastic stress field. For K-controlled crack growth, Ni-base alloys typically exhibit a large-crack growth threshold, $K_{\text {th }}$, below which time-dependent crack growth does not occur. The magnitude of the $K_{\mathrm{th}}$ is usually higher than the large-crack fatigue crack threshold, $\Delta K_{\mathrm{th}} \cdot{ }^{[2,14-17,19]}$ Neither the origin nor the magnitude of the time-dependent crack growth threshold, $K_{\mathrm{th}}$, is well understood for oxidation, stress corrosion, or creep crack growth. On the other hand, the crack growth rates during dwell fatigue at elevated temperature in air are significantly higher than

KWAI S. CHAN, Institute Scientist, is with the Southwest Research Institute, San Antonio, TX 78238. Contact e-mail: kchan (a) swri.org

Manuscript submitted October 10, 2013.

Article published online April 5, 2014 the crack growth rates under pure fatigue in air at the same temperature and stress intensity range, $\Delta K$, levels. Ni-base superalloys in advanced turbo-propulsion systems operate at severe temperature and environments where competing cycle-dependent and time-dependent crack growth mechanisms may be operative concurrently. ${ }^{[21]}$ Thus, there is a need for a better understanding of the interactions between cycle-dependent and time-dependent crack growth at the respective near-threshold regimes.

Cycle-dependent fatigue crack growth and timedependent crack growth are generally treated as two independent processes whose crack growth increment, $d a$, over a mission can be summed according to the expression given by ${ }^{[19-21]}$

$$
(d a)_{\text {mission }}=\left(\frac{d a}{d N}\right)_{\text {cyclic }} d N+\left(\frac{d a}{d t}\right) d t,
$$

where the first term on the right-hand-side of Eq. [1] treats cycle-dependent crack growth, while the second term treats time-dependent crack growth for an arbitrary loading history within a mission. For fatigue crack growth test data generated under a constant frequency with dwell, Eq. [1] can be expressed as ${ }^{[19-21]}$

$$
\left(\frac{d a}{d N}\right)_{\mathrm{dwell}}=\left(\frac{d a}{d N}\right)_{\text {cyclic }}+\left[t_{\mathrm{dwell}}+1 / f\right]\left(\frac{d a}{d t}\right),
$$

where $t_{\mathrm{dwell}}$ is the dwell time, and $f$ is the frequency of the dwell fatigue cycles. To obtain the crack growth life, Eq. [2] is integrated over the fatigue cycle. The 
fatigue crack growth rate, $d a / d N$, can be represented in terms of the Paris power-law, ${ }^{[22]}$ as given by

$$
\frac{d a}{d N}=A \Delta K^{n} \quad \text { for } \Delta K>\Delta K_{\mathrm{th}}
$$

where $\Delta K$ is the stress intensity range, $\Delta K_{\text {th }}$ is the largecrack crack growth threshold, and $A$ and $n$ are material constants. Cyclic crack growth generally follows a transgranular path, while time-dependent crack growth due to stress-assisted grain boundary oxidation typically follows an intergranular path. ${ }^{[1-9,13-18]}$ The transition from transgranular fracture to intergranular fracture depends on the temperature, load frequency, and hold time. In general, time-dependent crack growth under K-controlled conditions can be expressed as ${ }^{[21,23]}$

$$
\frac{d a}{d t}=B_{\mathrm{o}} \exp \left(-\frac{Q}{R T}\right) K^{m} \text { with } m>0 \text { and } K>K_{\mathrm{th}},
$$

where $K_{\text {th }}$ is the static crack growth threshold, and $B_{\mathrm{o}}$ is an empirical constant.

A number of investigations have successfully applied Eqs. [1] and [2] to treat concurrent cycle-dependent and time-dependent crack growth such as dwell fatigue in Ni-base superalloys. ${ }^{[2,19-21,24]}$ According to Eqs. [1] through [4], time-dependent crack growth is dominant at long dwell times and low frequencies, provided that $K_{\max }>K_{\text {th }}$, where $K_{\max }$ is the maximum stress intensity factor in a loading cycle. In contrast, crack growth is entirely dominated by the cycle-dependent term, $d a / d N$, at $K_{\max }<K_{\mathrm{th}}$, since $d a / d t=0$ in this regime. Equation [4] suggests that a potential means of suppressing timedependent crack growth in Ni-base and other metallic alloys is to increase the threshold, $K_{\mathrm{th}}$. Unfortunately, the origins of $K_{\text {th }}$ are poorly understood, and a methodology for predicting the $K_{\mathrm{th}}$ values for the various timedependent crack growth processes (oxidation, stress corrosion, hot corrosion, and creep) does not appear to exist at this time. Once $K_{\mathrm{th}}$ is maximized, the values of $B_{\mathrm{o}}$ and $m$ in Eq. [4] may also need to be minimized in order to reduce the time-dependent crack growth rate.

The damage mechanisms accompanying creep crack growth are the formation, growth, and coalescence of creep cavities along grain boundaries (g.b.) and intergranular fracture. Creep crack growth by g.b. cavitation is observed in Ni-based alloys tested in vacuum or in an inert atmosphere, ${ }^{[1,17,19]}$ but it is also observed in $\gamma^{\prime}$-strengthened Ni-base alloys such as IN 738 and IN 939 tested in air. ${ }^{[24,25]}$ For oxidation-induced crack growth and stress corrosion cracking, the degradation processes are the formation and growth of oxides along grain boundaries, and the corresponding crack paths are also predominantly intergranular..$^{[1-9,13-18]}$ For IN 718, the crack-tip oxidation processes during sustained load crack growth in air involved the formation of $\mathrm{NiO}$ and $\mathrm{Cr}_{2} \mathrm{O}_{3}$ along grain boundaries. ${ }^{[4,5,7]}$ The oxidation of grain boundary particles such as $\mathrm{NbC}$ during sustained load crack growth in air and in oxygen environment ${ }^{[26]}$ or fatigue in air ${ }^{[27]}$ was also reported by some investigators. For dwell fatigue of RR1000, the crack-tip oxides were reported to be $\mathrm{NiO}$ and $\mathrm{Cr}_{2} \mathrm{O}_{3} \cdot{ }^{[28]}$ More recently, Gabb et al. ${ }^{[29]}$ reported that during dwell fatigue of ME3 (Rene 104), the oxidation products consisted of a continuous outer layer of Ni-rich and Co-rich oxides on top of underlying Al-rich oxide fingers. The oxides associated with stress corrosion cracking were predominantly $\mathrm{CrO}$ mixed with $\mathrm{Cr}_{2} \mathrm{O}_{3}$ in Alloy 690 $0^{[30]}$ compared to $\mathrm{NiO}$ and $\mathrm{Fe}_{2} \mathrm{O}_{3}$ in Alloy 600. ${ }^{[31]}$ According to Chan et al., ${ }^{[23]}$ most of these oxides exhibit a volume expansion when formed in Ni-base alloys and may induce crack-tip shielding and transformation toughening during time-dependent crack growth.

The objective of this paper is to present the results of an investigation focused on developing a micromechanical model for predicting the time-dependent crack growth threshold and its variability in a large crack subjected to a sustained load at elevated temperatures in air. The damage mechanisms considered include oxidation, creep, and stress corrosion cracking. The micromechanical models have been developed by considering the crack-tip stress field associated with the formation of a damage zone containing oxides or creep cavities along a grain boundary located ahead of an elastic crack. It is demonstrated that stress relaxation associated with a volume-expansion process such as the formation of creep cavities or the formation of oxides with a positive transformation strain can induce near-tip residual stresses that must be overcome by the external load, thereby instigating a growth threshold for the onset of time-dependent crack growth. This micromechanical framework provides the basis for developing appropriate predictive models for the time-dependent crack growth thresholds associated with damage mechanisms such as (1) oxidation-assisted intergranular crack growth, ${ }^{[1-9]}$ (2) creep crack growth along an intergranular path, ${ }^{[12-17]}$ and (3) stress corrosion cracking. ${ }^{[11,30,31]}$ The micromechanical threshold models have been utilized to predict the time-dependent crack growth thresholds of Ni-base superalloys used in turbo-propulsion systems. The sources of material variability in values of time-dependent crack growth threshold have been identified, and they can be related to mixed oxides or creep cavities formed near the crack tip. A size scale effect is also predicted for the transformation toughening phenomenon, which is largest at or below $K_{\text {th }}$ and diminishes at increasing $K$ levels above the threshold. Finally, the micromechanical models are utilized to identify means for suppressing time-dependent crack growth in Ni-base alloys.

\section{MODEL DEVELOPMENT}

\section{A. Crack-Tip Stress Field}

An elastic crack in a Ni-base superalloy subjected to a sustained load at elevated temperature in air is considered as the starting point for the modeling effort in this article. The effects of crack-tip stress relaxation on $K_{\text {th }}$ will be discussed in Section IV later in this article. The normal stress, $\sigma_{y y}$, associated with the K-field directly ahead of the crack tip is given by ${ }^{[32,33]}$

$$
\sigma_{y y}=\frac{K}{\sqrt{2 \pi r}}
$$

where $r$ is distance ahead of the crack tip. A damage zone due to oxidation, Figure 1(a), or grain boundary 


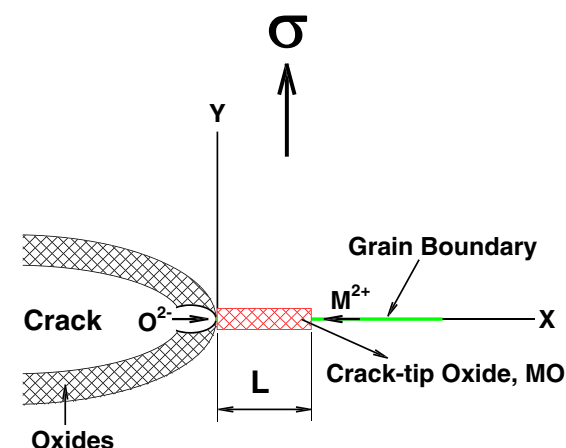

(a)

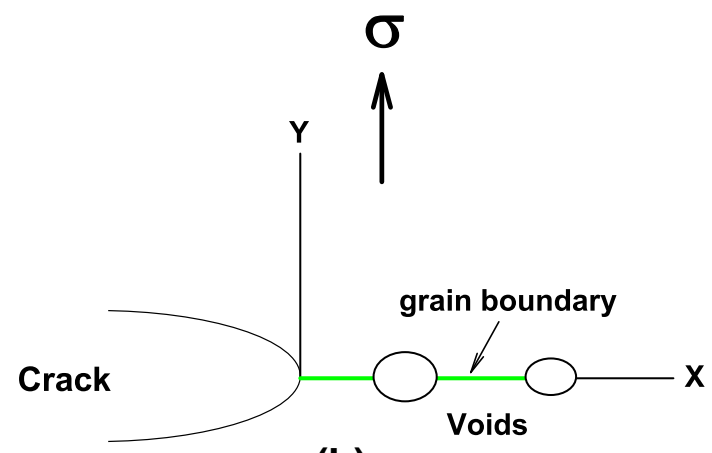

(b)

Fig. 1-Schematics depict the formation of oxides and creep cavities along a grain boundary located ahead of an elastic crack subjected to a static stress, $\sigma:(a)$ crack-tip oxide formation and $(b)$ grain boundary cavitation.

cavitation, Figure 1(b), is considered to develop ahead of the crack tip. In Figure 1(a), the damage process is envisioned to be the result of an ingress of oxygen from the air environment into the crack-tip region to form an oxide $\mathrm{MO},{ }^{[3,6]}$ where $\mathrm{M}$ is a metallic element in a variety of potential reactants including (1) $\mathrm{Ni}$ solid solution matrix containing $\mathrm{Ni}, \mathrm{Cr}, \mathrm{Co}, \mathrm{Ti}$, or other metals typically found in a Ni-based alloy, (2) alloyed $\gamma^{\prime}$ and $\gamma^{\prime \prime}$, and (3) carbides, intermetallic, or Laves phases at grain boundaries. The reaction of $\mathrm{M}$ and $\mathrm{O}$ to form $\mathrm{MO}$ results in a transformation strain, $\varepsilon_{\mathrm{tr}}$, which is defined as

$$
\varepsilon_{\mathrm{tr}}=\frac{\Delta V}{V_{\mathrm{o}}}=\frac{V_{\mathrm{ox}}}{V_{\mathrm{o}}}-1,
$$

where $\Delta V=V_{\mathrm{ox}}-V_{\mathrm{o}}$ is the volume change associated with the formation of the MO oxide, and $V_{\mathrm{o}}$ is the volume of the unit cell containing the reactant that reacts with oxygen to form the oxide product. In most cases, $\mathrm{Ni}$ solid solution, $\mathrm{Ni}_{\mathrm{ss}}$, containing the reactive element $\mathrm{M}$ is considered the reactant, but reactive element from $\mathrm{MC}, \mathrm{M}_{26} \mathrm{C}_{6}$, alloyed $\mathrm{Ni}_{3} \mathrm{Al}$, or alloyed $\mathrm{Ni}_{3} \mathrm{Nb}$ is also considered. According to this definition, the transformation strain is positive when the unit-cell volume of the oxide is larger than that of the reactant but is negative when the reverse is true. Applying the Eshelby method ${ }^{[34]}$ in a manner shown by Shi and $\mathrm{Puls}^{[35]}$ in an analysis of hydride formation in Zirconium alloys, the formation of a second phase (oxide in this case) in a metallic matrix induces a transformation stress in the matrix, which is given by ${ }^{[34,35]}$

$$
\sigma_{\mathrm{tr}}=-\frac{\beta E_{\mathrm{ox}} \varepsilon_{\mathrm{tr}} t_{\mathrm{ox}}}{\left(1-v^{2}\right) L}
$$

where $E_{\mathrm{ox}}, v, t_{\mathrm{ox}}$, and $L$ are, respectively, the Young's modulus, Poisson's ratio, oxide thickness, and length of the second phase (oxide in this case) formed; $\beta$ is a geometric shape factor of the second phase formed. The parameter $\beta=\pi / 4$ for a thin plate, ${ }^{[35]}$ as assumed here for an oxide layer formed along a grain boundary located ahead of the crack tip. The near-tip $\sigma_{y y}$ stress distribution resulting from the elastic crack and the oxide formation can be obtained by superposition and summing Eqs. [1] and [3], leading to

$$
\sigma_{y y}=\frac{K}{\sqrt{2 \pi r}}-\frac{\beta E_{\mathrm{ox}} \varepsilon_{\mathrm{tr}} t_{\mathrm{ox}}}{\left(1-v^{2}\right) L}
$$

which values are plotted in Figures 2(a) and (b) for $K$ levels of 10 and $30 \mathrm{MPa}(\mathrm{m})^{1 / 2}$, respectively. In Figure 2, the stresses are plotted as a function of distance $r$ ahead of the crack tip. The material parameters chosen correspond to the formation of $\mathrm{CrO}$, as shown in Figure 2. In the K-field, $\sigma_{y y}$ shows $r^{-1 / 2}$ dependence, while the transformation stress shows $L^{-1}$ dependence. The crack-tip elastic stresses are relaxed by the compressive transformation stresses when transformation toughening occurs ahead of the crack tip. ${ }^{[36]}$ At $K=10 \mathrm{MPa}(\mathrm{m})^{1 / 2}$, the relaxed crack-tip stress distribution after oxide formation is compressive over a small distance (about $110 \mu \mathrm{m}$ ) ahead of the crack tip as shown in Figure 2(a). At $K=30 \mathrm{MPa}(\mathrm{m})^{1 / 2}$, the extent of the compressive stress is reduced significantly to about $10 \mu \mathrm{m}$, and a tensile stress peak forms ahead of the crack tip, Figure 2(b). Further ahead of the crack tip, the relaxed crack-tip stresses are tensile and approach those of an elastic crack. Thus, the stabilization effect of the compressive stresses associated with the oxide formation is most effective at low $K$ levels and diminishes with increasing $K$ levels. The observed $K$ dependence of the relaxed stress field due to oxide transformation strongly suggests that a threshold stress intensity factor, $K_{\mathrm{th}}$, must be exceeded in order to cause fracture of an oxide layer formed ahead of the crack tip.

\section{B. $K_{\text {th }}$ for Crack-Tip Oxide Fracture}

The threshold, $K_{\text {th }}$, for oxidation-induced time-dependent crack growth along grain boundaries is derived by considering the fracture of oxide layer formed ahead of the crack tip. The local stress intensity factor at the crack tip, $K_{\text {tip }}$, is comprised of the applied $K$ due to the remote load and the shielding term, $K_{\mathrm{s}}$, resulting from the compressive transformation stresses induced by oxide formation ahead of the crack tip, as given by ${ }^{[37]}$

$$
K_{\text {tip }}=K-\sqrt{\frac{2}{\pi}} \int_{0}^{L} \frac{\sigma_{\text {tr }} d x}{\sqrt{x}}=K_{\text {ox }},
$$

where $x$ is distance ahead of the crack tip. At a very small distance ahead of the crack tip, the elastic 


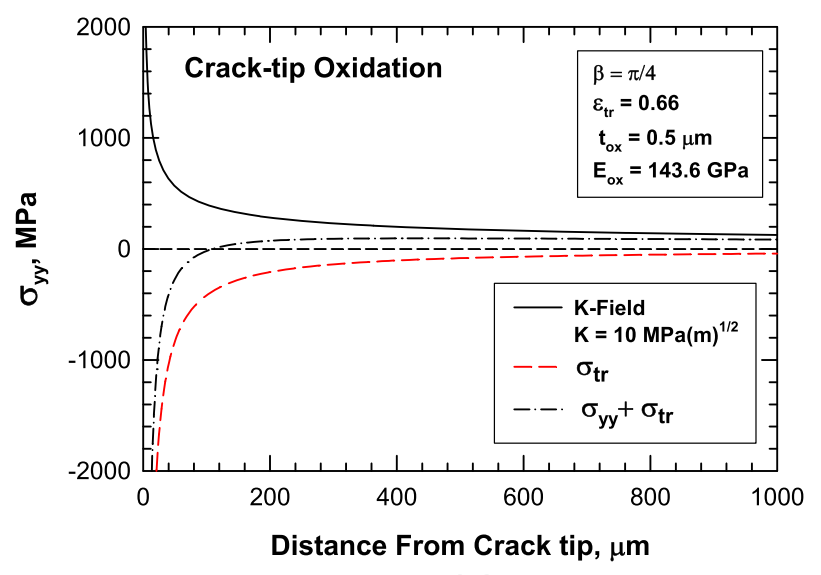

(a)

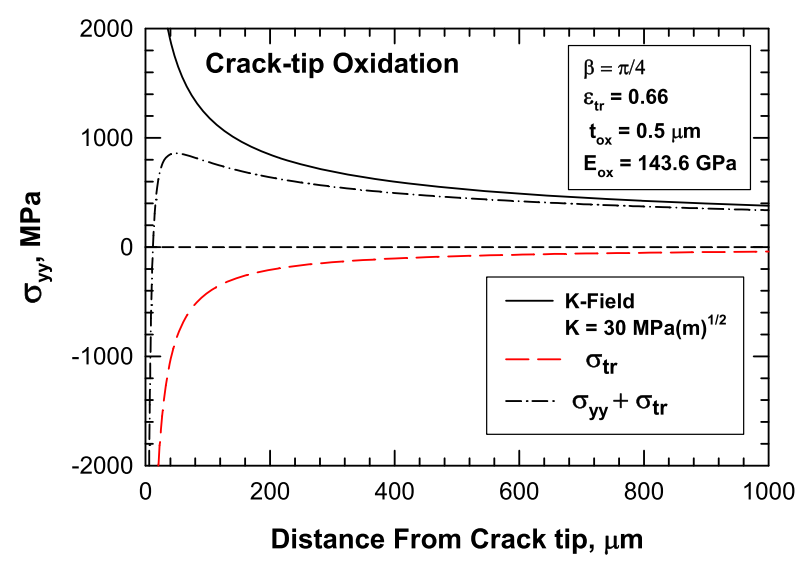

(b)

Fig. 2-Relaxed stress field associated with oxidation-induced transformation toughening ahead of an elastic crack loaded under a static stress: $(a) K=10 \mathrm{MPa}(\mathrm{m})^{1 / 2}$, and $(b) K=30 \mathrm{MPa}(\mathrm{m})^{1 / 2}$. The near-tip compressive stress induced by oxide formation at the crack tip is overcome by the elastic crack-tip stress field when the $K$ level is increased to $30 \mathrm{MPa}(\mathrm{m})^{1 / 2}$, leading to a tensile stress peak head of the crack tip.

transformation stress, given by Eq. [7], can exceed the compressive yield stress. The damage zone, $L_{\mathrm{d}}$, can be defined as the region where the compressive yield stress is attained, and $L_{\mathrm{d}}$ is obtained from Eq. [7] by limiting $\sigma_{\mathrm{tr}}$ to $-\sigma_{y}$, resulting in

$$
L_{\mathrm{d}}=\left[\frac{\pi E_{\mathrm{ox}} \sigma_{y} \varepsilon_{\mathrm{tr}} t_{\mathrm{ox}}}{4\left(1-v^{2}\right)}\right]^{1 / 2}
$$

Substituting Eq. [10] into [9] and performing integration leads one to

$$
K_{\mathrm{th}}=K_{\mathrm{ox}}+2 \operatorname{sgn}\left(\varepsilon_{\mathrm{tr}}\right)\left[\frac{E_{\mathrm{ox}} \sigma_{y}\left|\varepsilon_{\mathrm{tr}}\right| t_{\mathrm{ox}}}{2\left(1-v^{2}\right)}\right]^{1 / 2}
$$

when fracture of the oxide layer is considered to commence when the $K_{\text {tip }}$ exceeds the fracture toughness, $K_{\text {ox }}$, of the oxide layer. In Eq. [11], $\operatorname{sgn}(x)$ is the sign function with $x$ as the dummy variable; $\operatorname{sgn}(x)=1$ when $x$ is positive, and $\operatorname{sgn}(x)=-1$ when $x$ is negative. Equation [11] indicates that $K_{\text {th }}$ depends on material parameters such as the oxide modulus, oxide thickness, transformation strain, and the yield stress of the alloy. The dependence of $K_{\mathrm{th}}$ on the yield stress of the $\mathrm{Ni}$ alloy can, at least conceptually, be utilized to consider the effects of grain size and cooling rate on time-dependent crack growth threshold. The dependence of $K_{\text {th }}$ on these material parameters is illustrated in Figure 3(a), through (c) as a function of the yield strength of the Ni-base alloy.

\section{C. $K_{\text {th }}$ for Stress Corrosion Cracking}

The damage process associated with stress corrosion cracking often involves the formation and fracture of a protective oxide layer at the crack tip. ${ }^{[30]}$ The crack-tip damage process involves the formation and fracture of an oxide layer along grain boundaries ahead of the crack tip, as depicted in Figure 1(a). On this basis, Eq. [11] is directly applicable to stress corrosion cracking, providing that the damage process is controlled by the fracture of the oxide film and not by the kinetics of passive film formation. The threshold, $K_{\mathrm{ISCC}}$, for the onset of stress corrosion cracking is then given by

$$
K_{\mathrm{ISCC}}=K_{\mathrm{ox}}+2 \operatorname{sgn}\left(\varepsilon_{\mathrm{tr}}\right)\left[\frac{E_{\mathrm{ox}} \sigma_{y}\left|\varepsilon_{\mathrm{tr}}\right| t_{\mathrm{ox}}}{2\left(1-v^{2}\right)}\right]^{1 / 2}
$$

when stress corrosion cracking is controlled by fracture of the protective oxide film at the crack tip.

\section{D. $K_{\text {th }}$ for Creep Crack Growth}

Creep crack growth involves the formation, growth, and coalescence of creep cavities along grain boundaries located ahead of the crack tip, ${ }^{[3,17,38,39]}$ as illustrated in Figure 1(b). To derive the $K_{\text {th }}$ for creep crack growth, cavity formation at a grain boundary is considered as a transformation process that involves coalescence of $n_{\mathrm{v}}$ vacancies to produce a cavity ${ }^{[11,40]}$ in the form an oblate ellipsoid. The volume of a void formed by the coalescence of $n_{\mathrm{v}}$ vacancies is given by

$$
V_{\text {void }}=\frac{4}{3} \beta \pi\left(n_{\mathrm{v}} a\right)^{3},
$$

where $n_{\mathrm{v}}$ is the number of vacancies, $a$ is the radius of a vacancy, and $\beta$ is a shape factor. The volume of $n_{\mathrm{v}}$ vacancies before coalescence is

$$
V_{\mathrm{o}}=\frac{4}{3} n_{\mathrm{v}} \pi a^{3}
$$

and the transformation strain associated with coalescing $n_{\mathrm{v}}$ vacancies into a single void is

$$
\varepsilon_{\mathrm{tr}}=\frac{V_{\mathrm{void}}}{V_{\mathrm{o}}}-1=\beta n_{\mathrm{v}}^{2}-1
$$

which becomes

$$
\varepsilon_{\mathrm{tr}}=\left(\frac{\pi}{4}\right)^{2} n_{\mathrm{v}}^{2}-1
$$

when the void is taken to be an oblate ellipsoid, and $\beta=(\pi / 4)^{2}$. Equation [16] indicates that the transformation strain associated with this cavity formation increases with increasing number of vacancies in the 




(a)



(b)

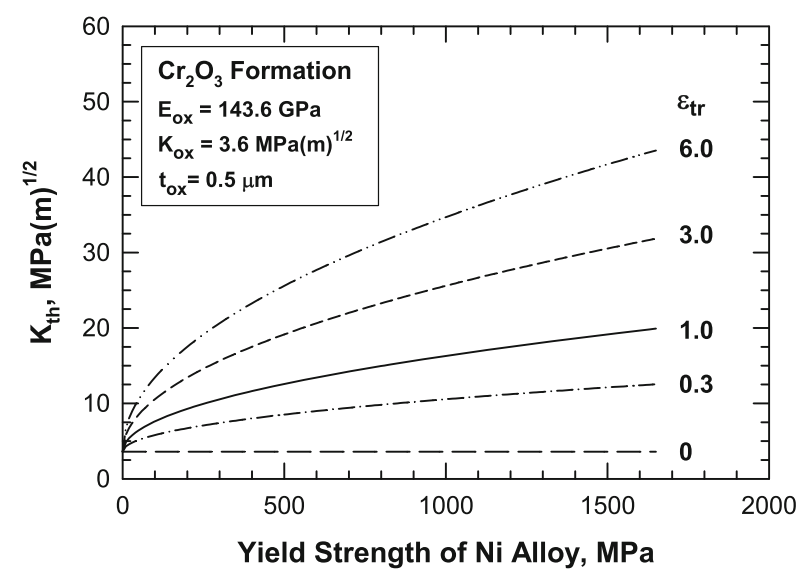

(c)

Fig. 3-Dependence of $K_{\text {th }}$ on Young's modulus, oxide thickness and transformation strain as a function of yield strength of $\mathrm{Ni}$ alloy: (a) Young's modulus of oxide, $E_{\mathrm{ox}},(b)$ oxide thickness, $t_{\mathrm{ox}}$, and $(c)$ transformation strain, $\varepsilon_{\mathrm{tr}}$, of oxide.

cavity formation process. The transformation stress takes a form that is similar to Eq. [7] and is given by

$$
\sigma_{\mathrm{tr}}=-\frac{\beta E \varepsilon_{\mathrm{tr}} t_{\mathrm{cd}}}{\left(1-v^{2}\right) L_{\mathrm{cd}}}
$$

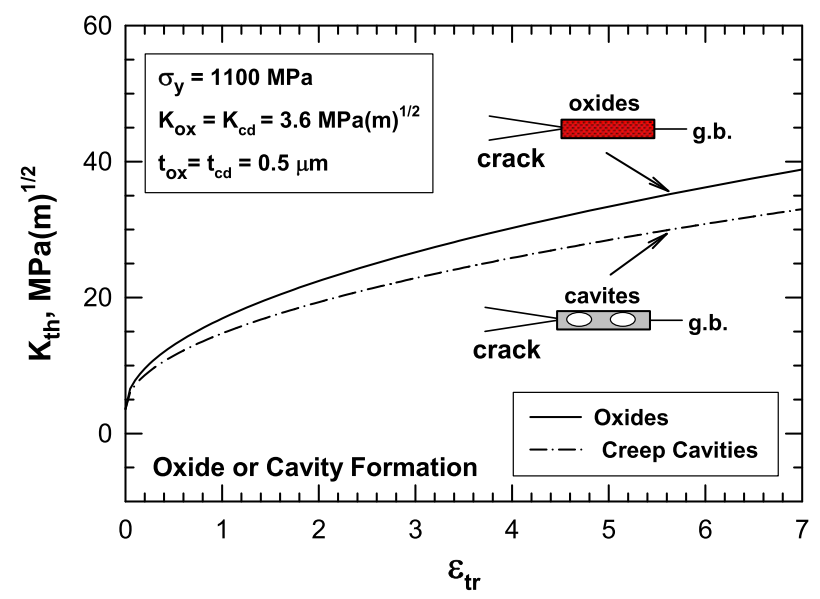

Fig. 4-Predicted $K_{\mathrm{th}}$ values as a function of transformation strain, $\varepsilon_{\text {tr }}$, for crack-tip oxidation formation compared to those for cavity formation along a g.b. located ahead of the crack tip.

where $E$ and $v$ are the Young's modulus and Poisson's ratio of the Ni-base alloy; $t_{\mathrm{cd}}$ and $L_{\mathrm{cd}}$ are the thickness and the length of the cavitated grain boundary layer, respectively. Using the same procedure described earlier, the $K_{\text {th }}$ expression is obtained from Eqs. [9] through [11], leading one to

$$
K_{\mathrm{th}}=K_{\mathrm{cd}}+2\left[\frac{E \sigma_{y} \varepsilon_{\mathrm{tr}} t_{\mathrm{cd}}}{2\left(1-v^{2}\right)}\right]^{1 / 2},
$$

where $K_{\mathrm{cd}}$ is the fracture toughness of the cavitated grain boundary. Figure 4 compares the $K_{\text {th }}$ values as a function of the transformation strain due to oxidation and cavity formation on time-dependent crack growth in Ni-base alloys. For these calculations, $t_{\mathrm{ox}}=t_{\mathrm{cd}}=$ $0.5 \mu \mathrm{m}, \sigma_{y}=1100 \mathrm{MPa}, E=100 \mathrm{GPa}, E_{\mathrm{ox}}=143.6 \mathrm{GPa}$, $v_{\mathrm{ox}}=v=0.33$, and $K_{\mathrm{ox}}=K_{\mathrm{cd}}=3.6 \mathrm{MPa}(\mathrm{m})^{1 / 2}$.

\section{MODEL APPLICATIONS}

The threshold model for oxide fracture, Eq. [11], was utilized to predict the $K_{\text {th }}$ for a number of Ni-base superalloys. Table I lists the names and compositions of the various Ni-base superalloys ${ }^{[4,41-47]}$ considered for the $K_{\text {th }}$ computations. To compute $K_{\text {th }}$, the properties of the oxide or oxides formed at the crack tip are required to assess oxidation-induced transformation toughening. The crystal structure, lattice parameters, Young's modulus $\left(E_{\mathrm{ox}}\right)$, and fracture toughness $\left(K_{\mathrm{ox}}\right)$, for selected oxides, carbides, and intermetallics are compiled from the literature, ${ }^{[4-63]}$ and the results are presented in Table II. Using information shown in Table II, relevant crack-tip oxidation reactions that may lead to transformation toughening in Ni-base superalloys are identified. Table III summarizes the metallic reactant, the volume of the unit cell containing the reactant, the unit cell of the oxide formed, Young's modulus, transformation strain, and oxide toughness. Using the listed properties and Eqs. [10] and [11], the length of the damage zone $\left(L_{\mathrm{d}}\right)$ and $K_{\mathrm{th}}$ were computed for an oxide thickness of 


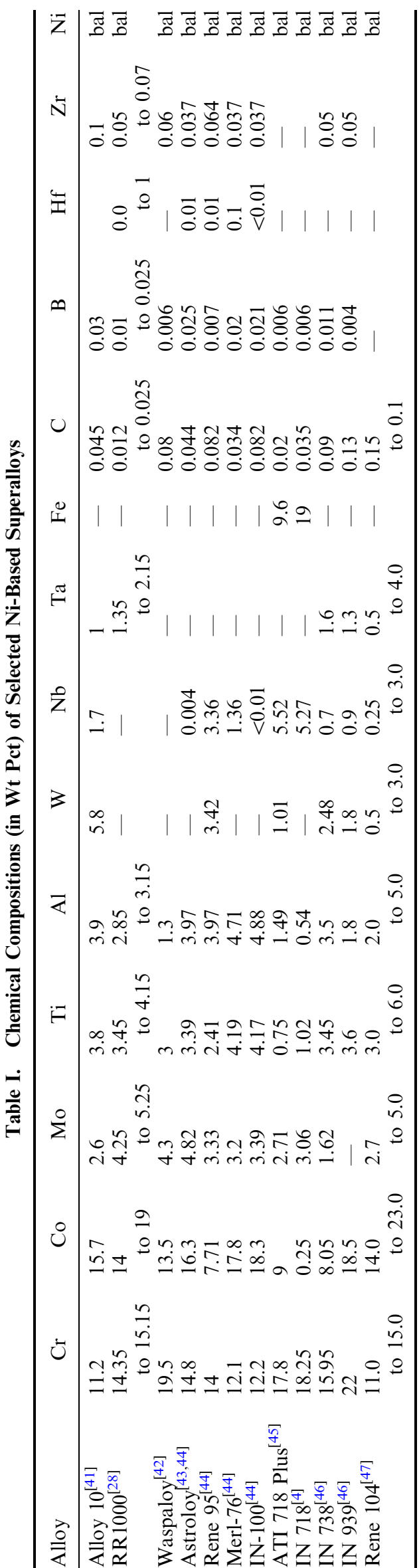

$0.25 \mu \mathrm{m}$ and yield strength of $1000 \mathrm{MPa}$. The results are presented at the last two columns in Table III. The results presented in Table III indicate that with the exception of $\mathrm{Nb}_{2} \mathrm{O}_{5}$, the transformation strains for the various oxides are positive, and the transformation stresses are compressive (negative). The consequence is that the $K_{\text {th }}$ values are relatively high and exceed $8.8 \mathrm{MPa}(\mathrm{m})^{1 / 2}$. In contrast, the oxidation of $\mathrm{Nb}$ in $\mathrm{Ni}_{\mathrm{ss}}$ to form $\mathrm{Nb}_{2} \mathrm{O}_{5}$ leads to a small transformation strain and a low $K_{\mathrm{th}},\left[3.6 \mathrm{MPa}(\mathrm{m})^{1 / 2}\right]$, while the oxidation of $\mathrm{NbC}$ and $\mathrm{Ni}_{3} \mathrm{Nb}$ to form $\mathrm{Nb}_{2} \mathrm{O}_{5}$ results in a negative transformation strain, a tensile transformation stress, and a negative $K_{\text {th }}$. A negative $K_{\text {th }}$ value means that fracture of the oxide is spontaneous once the oxide layer is formed, signifying an embrittlement process. Thus, formation of $\mathrm{Nb}_{2} \mathrm{O}_{5}$ at the crack tip in Ni-base alloys is expected to accelerate the time-dependent crack growth process. The opposite is true when oxides such as $\mathrm{NiO}$, $\mathrm{CrO}, \mathrm{CoO}, \mathrm{FeO}, \mathrm{Fe}_{2} \mathrm{O}_{3}, \mathrm{Al}_{2} \mathrm{O}_{3}, \mathrm{Cr}_{2} \mathrm{O}_{3}$, and $\mathrm{Fe}_{3} \mathrm{O}_{4}$ form at the crack tip by virtue of a positive transformation strain, compressive transformation stresses, and cracktip shielding.

The $K_{\mathrm{th}}$ values for various oxide formations are predicted as a function of yield strength using the oxide properties and transformation strains listed in Table III and an oxide layer of $0.25 \mu \mathrm{m}$, which was estimated based on micrographs of crack-tip oxide layers reported in the literature. ${ }^{[28]}$ The computed $K_{\text {th }}$ values for an oxide layer of $0.25 \mu \mathrm{m}$ are compared against experimental data ${ }^{[2,28,41-45,76-83]}$ for Ni-base superalloys in Figure 5. The experimental $K_{\text {th }}$ data include those of powder metallurgy (PM) and wrought alloys, which all exhibit oxidation-induced time-dependent crack growth. The experimental $K_{\text {th }}$ value ranges from 10 to 28 $\mathrm{MPa}(\mathrm{m})^{1 / 2}$, which is bounded by the calculated curves for $\mathrm{NiO}$ and $\mathrm{Cr}_{2} \mathrm{O}_{3}$. The calculated $K_{\text {th }}$ curves for $\mathrm{CrO}$ and $\mathrm{CoO}$ are lower than the observed values, while those for $\mathrm{TiO}_{2}$ and $\mathrm{Cr}_{2} \mathrm{O}_{3}$ are within the experimental scatter band. One possible way for rationalizing the $K_{\text {th }}$ variability observed in the Ni-base superalloys is that the type of oxides formed at the crack tip varies with alloy composition. For a given alloy composition, the $K_{\text {th }}$ may also vary because of the formation of mixed oxides at the crack tip and variations of the relative percentages of individual oxides in the mixed oxides. For illustration, the $K_{\text {th }}$ values were computed as a function of yield strength of $\mathrm{Ni}$ alloy in Figure 6 for various percentages of $\mathrm{NiO}$ and $\mathrm{Cr}_{2} \mathrm{O}_{3}$ formed at the crack tip. In Figure 6, the lower bound of the $K_{\text {th }}$ values is given by the curve with 100 pct $\mathrm{NiO}$, while the upper bound curve is given by the curve for 100 pet $\mathrm{Cr}_{2} \mathrm{O}_{3}$. On this basis, the variation of the $K_{\text {th }}$ value in Figure 6 can be attributed to variation in the amounts of $\mathrm{Cr}_{2} \mathrm{O}_{3}$ oxides formed at the crack tip. A similar comparison of $\mathrm{Ni}$ alloy for various percentages of $\mathrm{NiO}$ and $\mathrm{Al}_{2} \mathrm{O}_{3}$ is presented in Figure 7. The agreement between model calculation and experimental data is better in Figure 6 than in Figure 7, because most of Ni-based superalloys shown are predominantly chromia formers rather than alumina formers. Experimentally, $\mathrm{Al}_{2} \mathrm{O}_{3}$ or $\mathrm{Cr}_{2} \mathrm{O}_{3}$ was observed to form underneath an outer $\mathrm{NiO}$ oxide layer. ${ }^{[28-30]}$ Under these circumstances, the variability 
Table II. Summary of the Compound, Crystal Structure, Lattice Parameter, Unity Cell Volume, Elastic Modulus (E), and Fracture Toughness $\left(K_{\mathrm{IC}}\right)$ of Individual Constituent Phases Pertinent for Consideration of Oxidation-Induced Transformation Toughening in Ni-Based Alloys

\begin{tabular}{|c|c|c|c|c|c|}
\hline Compound & Crystal Structure & Lattice Parameters $(\AA)$ & Unit-cell Volume $\left(\AA^{3}\right)$ & $E(\mathrm{GPa})$ & $K_{\mathrm{IC}}\left[\mathrm{MPa}(\mathrm{m})^{1 / 2}\right]$ \\
\hline $\mathrm{Ni}_{\mathrm{ss}}$ & Fcc & $a_{\mathrm{o}}=3.529^{[48]}$ & 41.61 & $200^{[71]}$ & 96 to $131^{[70]}$ \\
\hline $\mathrm{NbC}$ & Fcc & $a_{\mathrm{o}}=4.470^{[51,52]}$ & 93.91 & 340 to $400^{[54]}$ & 3.0 to $4.0^{[54]}$ \\
\hline $\mathrm{Ni}_{3} \mathrm{Nb}$ & Bct & $a_{\mathrm{o}}=3.655 ; c_{\mathrm{o}}=7.495^{[48,49]}$ & 100.13 & 200 & 6.0 to $8.0^{[55]}$ \\
\hline $\mathrm{M}_{6} \mathrm{C}$ & Cubic & $a_{\mathrm{o}}=10.62^{[51]}$ & 1197.8 & - & $7.1^{[56]}$ \\
\hline $\mathrm{M}_{23} \mathrm{C}_{6}$ & Cubic & $a_{\mathrm{o}}=10.63^{[51,53]}$ & 1201.2 & 325 to $334^{[57]}$ & $7.1^{[56]}$ \\
\hline $\mathrm{Ni}_{3} \mathrm{Al}$ & Cubic & $a_{\mathrm{o}}=3.57$ to $3.60^{[48-50]}$ & 45.5 & $178^{[58]}$ & $30^{[58]}$ \\
\hline $\mathrm{Cr}_{2} \mathrm{O}_{3}$ & Hcp & $a_{\mathrm{o}}=4.961 ; c_{\mathrm{o}}=13.6^{[63]}$ & 289.87 & $143.6^{[59,60]}$ & $3.6^{[59,60]}$ \\
\hline $\mathrm{Al}_{2} \mathrm{O}_{3}$ & Hcp & $a_{\mathrm{o}}=4.785 ; c_{\mathrm{o}}=12.991^{[64]}$ & 257.59 & $362^{[54,59,60]}$ & $3.5^{[54,59,60]}$ \\
\hline $\mathrm{TiO}_{2}$ & tetragonal & $a_{\mathrm{o}}=3.784 ; c_{\mathrm{o}}=9.514^{[65]}$ & 136.27 & $270.7^{[59,60]}$ & $2.49^{[59,60]}$ \\
\hline $\mathrm{Nb}_{2} \mathrm{O}_{5}$ & Hcp & $a_{\mathrm{o}}=3.607 ; c_{\mathrm{o}}=3.925^{[66]}$ & 44.22 & $125^{[61]}$ & 1.5 \\
\hline $\mathrm{CoO}$ & cubic & $a_{\mathrm{o}}=4.254^{[67,68]}$ & 75.44 & $189^{[66]}$ & $1.12^{[62]}$ \\
\hline $\mathrm{NiO}$ & cubic & $a_{\mathrm{o}}=4.173^{[66,68]}$ & 72.67 & 230 to $260^{[62,63]}$ & $1.5^{[62]}$ \\
\hline $\mathrm{CrO}$ & cubic & $a_{\mathrm{o}}=4.1^{[69]}$ & 68.92 & — & 1.5 \\
\hline $\mathrm{NiCr}_{2} \mathrm{O}_{4}$ & cubic & $a_{\mathrm{o}}=8.32^{[70]}$ & 573.9 & $106.6^{[62]}$ & $0.57^{[62]}$ \\
\hline $\mathrm{FeO}$ & cubic & $a_{\mathrm{o}}=4.334^{[72]}$ & 81.41 & $130^{[74]}$ & $1.7^{[75]}$ \\
\hline$\alpha-\mathrm{Fe}_{2} \mathrm{O}_{3}$ & rhombohedral & $a_{\mathrm{o}}=4.99 ; c_{\mathrm{o}}=13.61^{[73]}$ & 338.6 & $219^{[74]}$ & $1.7^{[75]}$ \\
\hline$\gamma-\mathrm{Fe}_{2} \mathrm{O}_{3}$ & cubic & $a_{\mathrm{o}}=8.40^{[73]}$ & 591.92 & $208^{[74]}$ & $1.7^{[75]}$ \\
\hline
\end{tabular}

of $K_{\text {th }}$ may be directly attributed to the variations of the $\mathrm{NiO}, \mathrm{Al}_{2} \mathrm{O}_{3}$, or $\mathrm{Cr}_{2} \mathrm{O}_{3}$ layers.

The creep crack growth thresholds for Ni-base alloys were predicted as a function of yield strength using Eq. [18] for a series of transformation strains ranging from 0 to 29.2, which corresponded to vacancies ranging from 1 to 7 . The fracture toughness of the cavitated grain boundary was taken to be $10 \mathrm{MPa}(\mathrm{m})^{1 / 2}$ in these calculations. The predicted $K_{\text {th }}$ values are compared against selected Ni-base alloys in Figure 8. IN 738 and IN 939 exhibit creep crack growth by grain boundary cavitation in air at $1123 \mathrm{~K}\left(850^{\circ} \mathrm{C}\right) .{ }^{[84]}$ IN 718 and $\mathrm{X}-750$ also exhibit creep crack growth by grain boundary cavitation at $923 \mathrm{~K}\left(650{ }^{\circ} \mathrm{C}\right)$ in vacuum. ${ }^{[14]}$ The $K_{\text {th }}$ values of these alloys range from about $18 \mathrm{MPa}(\mathrm{m})^{1 / 2}$ to as high as $50 \mathrm{MPa}(\mathrm{m})^{1 / 2}$. The corresponding transformation strain ranges from 1.47 to 29.2 , and the number of vacancies ranges from 2 to 7 as shown in Figure 8. It is noted that the transformation strain increases rapidly with $n_{\mathrm{v}}^{2}$, and $K_{\text {th }}$ increases with increasing transformation strain.

\section{DISCUSSION}

One of the significant findings of this investigation is the demonstration that oxide formation at the crack tip can induce transformation toughening at the crack tip and results in a threshold stress intensity factor that must be exceeded prior to fracture of an oxide layer formed within the oxidation damage zone. The origin of the timedependent crack growth threshold is the compressive stresses associated with the oxide formation at the crack tip. A deeper understanding of the oxide fracture at the crack tip can be developed by examining the near-tip stress distribution of a crack tip with an oxide layer as a function of the applied $K$ level. Figure 9 indicates that at
$K=10 \mathrm{MPa}(\mathrm{m})^{1 / 2}$, compressive stresses act on the oxide damage zone due to a positive transformation strain associated with $\mathrm{MO}$ or $\mathrm{M}_{2} \mathrm{O}_{3}$ formations at the crack tip, the only exception being $\mathrm{Nb}_{2} \mathrm{O}_{5}$. Both the magnitude and the size of the compressive stress zone decrease with increasing $K$ levels, as shown in Figure 9. Such a crack-tip stress field associated with stress-assisted grain boundary oxidation $^{[85]}$ in the form of an oxide layer formed ahead of a loaded crack tip was pointed out independently by Evans et al. ${ }^{[86]}$ At $K$ levels at or above $30 \mathrm{MPa}(\mathrm{m})^{1 / 2}$, a tensile stress peak develops ahead of the crack tip which extends over a substantial portion of the oxide layer. Thus, substantial tensile stresses exist at the crack tip to cause fracture of oxide layer, once the $K_{\text {th }}$ is exceeded. The exact value of the $K_{\text {th }}$ depends on the reactants and the oxides, the transformation strain, elastic properties, and thickness of the oxide, as well as the yield strength of the Ni-base alloy matrix. For the Ni-base alloys and oxides examined, the $K_{\text {th }}$ value ranges from about 10 to $25 \mathrm{MPa}(\mathrm{m})^{1 / 2}$, as shown in Figures 5, 6, and 7.

Crack-tip shielding due to transformation toughening extends beyond the growth threshold and influences the entire crack growth curve including the power-law regime. From Eq. [9], it is clear that for $K>K_{\mathrm{th}}$,

$$
K_{\text {tip }}=K-2 \operatorname{sgn}\left(\varepsilon_{\mathrm{tr}}\right)\left[\frac{E_{\mathrm{ox}} \sigma_{y}\left|\varepsilon_{\mathrm{tr}}\right| t_{\mathrm{ox}}}{2\left(1-v^{2}\right)}\right]^{1 / 2},
$$

which can be combined with Eq. [4] to give

$$
\begin{aligned}
& \frac{d a}{d t}=B_{\mathrm{o}} \exp \left(-\frac{Q}{R T}\right)\left[K-2 \operatorname{sgn}\left(\varepsilon_{\mathrm{tr}}\right)\left[\frac{E_{\mathrm{ox}} \sigma_{y}\left|\varepsilon_{\mathrm{tr}}\right| t_{\mathrm{ox}}}{2\left(1-v^{2}\right)}\right]\right]^{m} \\
& \text { with } m>0 \text { and } K>K_{\mathrm{th}},
\end{aligned}
$$

where $K_{\text {th }}$ is the static crack growth threshold given by Eq. [11]. From Eq. [20], it is obvious that material 


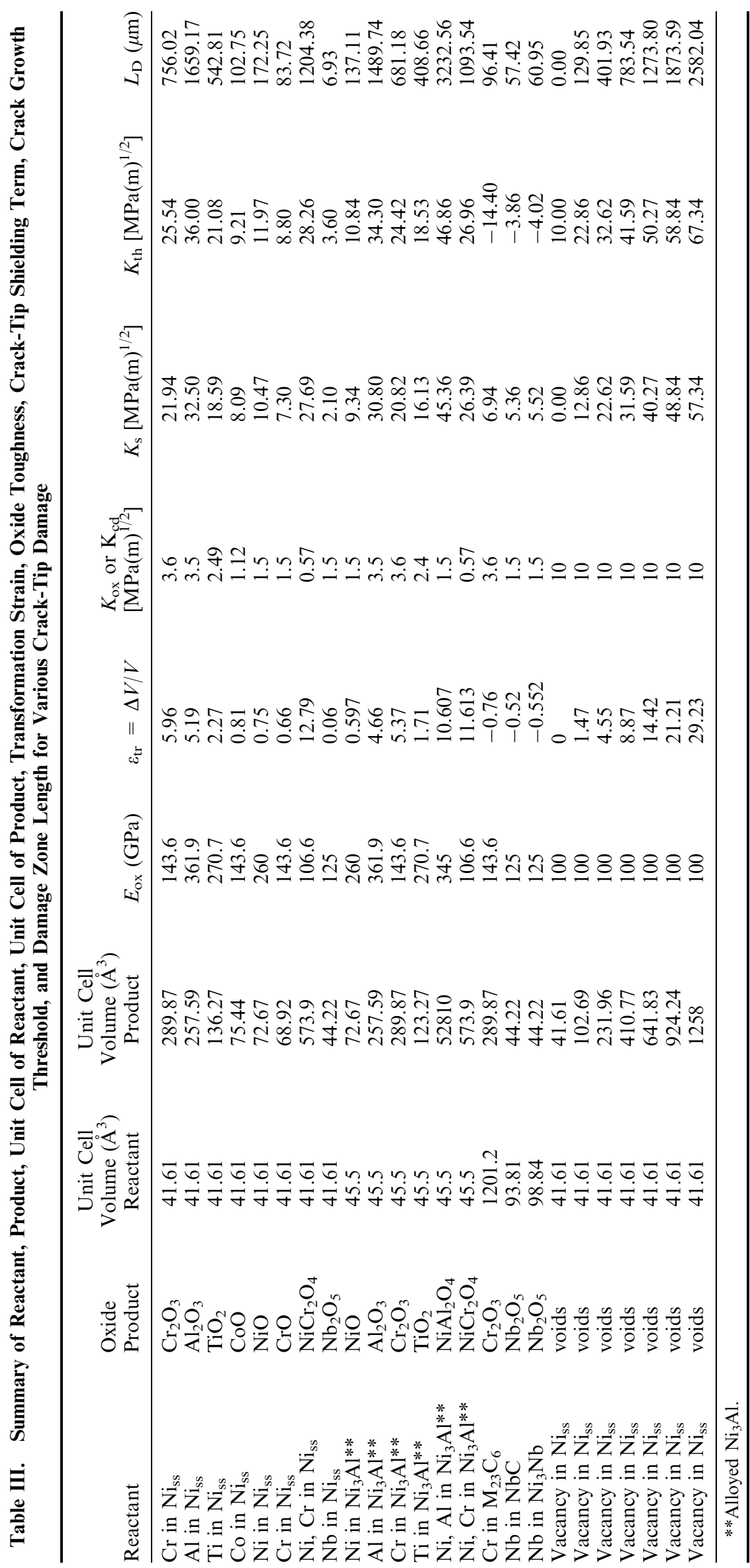




\begin{tabular}{|c|c|c|c|c|}
\hline \multicolumn{2}{|c|}{ Wrought Alloys } & \multicolumn{3}{|c|}{ PM Alloys } \\
\hline & $\begin{array}{l}\text { Alloy } 718,650^{\circ} \mathrm{C} \\
{[2,77-81]}\end{array}$ & 0 & $\begin{array}{l}\text { Rene } 95,650^{\circ} \mathrm{C} \\
{[44,82,83]}\end{array}$ & Alloy $10,704^{\circ} \mathrm{C}[41]$ \\
\hline$\nabla$ & Waspaloy, $650^{\circ} \mathrm{C}[42]$ & $\square$ & Astroloy, $704^{\circ} \mathrm{C}$ [44] & MERL-76, $704^{\circ} \mathrm{C}[44]$ \\
\hline$\nabla$ & $\begin{array}{l}\text { ATI } 718 \text { Plus, } \\
704^{\circ} \mathrm{C}[45]\end{array}$ &  & $\begin{array}{l}\text { Rene } 104,704^{\circ} \mathrm{C}[76] \triangle \\
\text { IN } 100 \mathrm{LC}, 704^{\circ} \mathrm{C}[44]\end{array}$ & RR $1000,704^{\circ} \mathrm{C}[28]$ \\
\hline
\end{tabular}

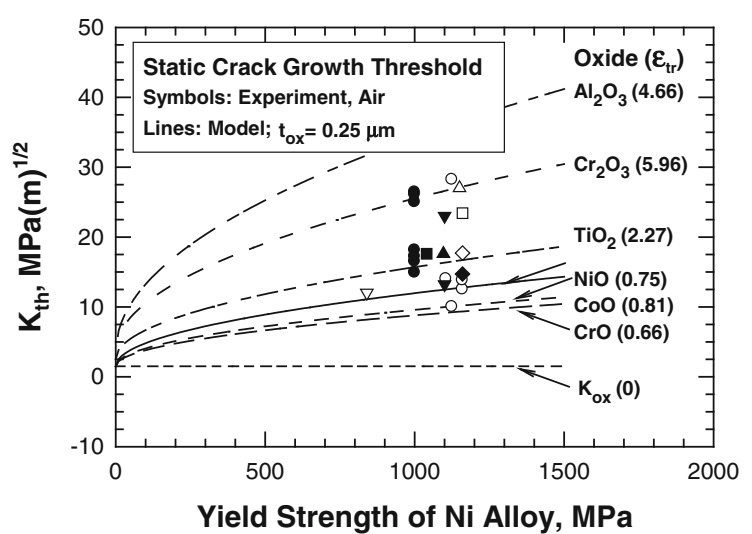

Fig. 5-A comparison of predicted and observed $K_{\text {th }}$ values for Ni-base superalloys. The oxides assumed in the model computations are indicated with the corresponding transformation strain values. Experimental data are taken from the literature. ${ }^{[2,28,41,42,44,45,76-83]}$

\begin{tabular}{|c|c|c|c|c|}
\hline \multicolumn{2}{|c|}{ Wrought Alloys } & \multicolumn{3}{|c|}{ PM Alloys } \\
\hline & $\begin{array}{l}\text { Alloy } 718,650^{\circ} \mathrm{C} \\
{[2,77-81]}\end{array}$ & 0 & $\begin{array}{l}\text { Rene } 95,650^{\circ} \mathrm{C} \\
{[44,82,83]}\end{array}$ & Alloy $10,704^{\circ} \mathrm{C}[41]$ \\
\hline$\nabla$ & Waspaloy, $650^{\circ} \mathrm{C}$ [42] & $\square$ & Astroloy, $704^{\circ} \mathrm{C}[44]$ & MERL-76, $704^{\circ} \mathrm{C}[44]$ \\
\hline$\nabla$ & $\begin{array}{l}\text { ATI } 718 \text { Plus, } \\
704^{\circ} \mathrm{C} \text { [45] }\end{array}$ & $\diamond$ & $\begin{array}{l}\text { Rene } 104,704^{\circ} \mathrm{C}[76] \triangle \\
\text { IN } 100 \mathrm{LC}, 704^{\circ} \mathrm{C}[44]\end{array}$ & RR $1000,704^{\circ} \mathrm{C}[28]$ \\
\hline
\end{tabular}



Fig. 7-A comparison of predicted and observed $K_{\text {th }}$ values for Ni-base superalloys. The oxide mixture assumed in the model computations is $\mathrm{NiO}$ and $\mathrm{Al}_{2} \mathrm{O}_{3}$ in various percentages ranging from 0 to 100 pct. Experimental data are taken from the literature. ${ }^{[2,28,41,42,44,45,76-83]}$
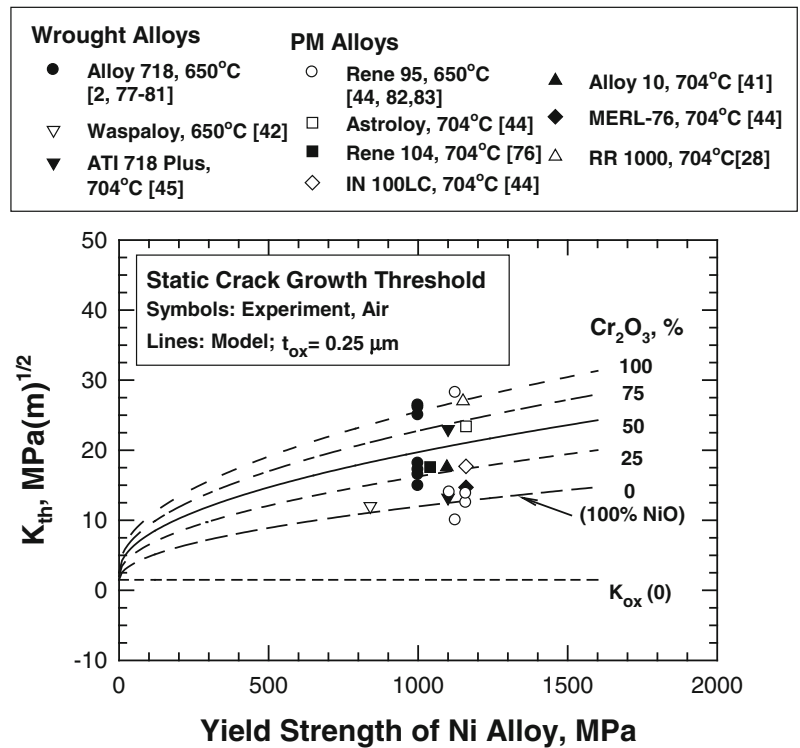

Fig. 6-A comparison of predicted and observed $K_{\text {th }}$ values for Ni-base superalloys. The oxide mixture assumed in the model computations is $\mathrm{NiO}$ and $\mathrm{Cr}_{2} \mathrm{O}_{3}$ in various percentages ranging from 0 to 100 pct. Experimental data are taken from the literature. ${ }^{[2,28,41,42,44,45,76-83]}$

parameters that enhance $K_{\text {th }}$ also reduce the crack growth rates at $K>K_{\text {th }}$ by reducing the near-tip crack driving force. The beneficial effects of transformation toughening, however, diminish with increasing $\mathrm{K}$ levels above $K_{\text {th }}$ as the relaxed crack-tip stress field approaches the K-field, as shown in Figure 9.

The near-tip stress field shown in Figure 9 explains the dichotomy that oxidation enhances the time-dependent crack growth rate, $d a / d t$, of Ni-base alloys while at

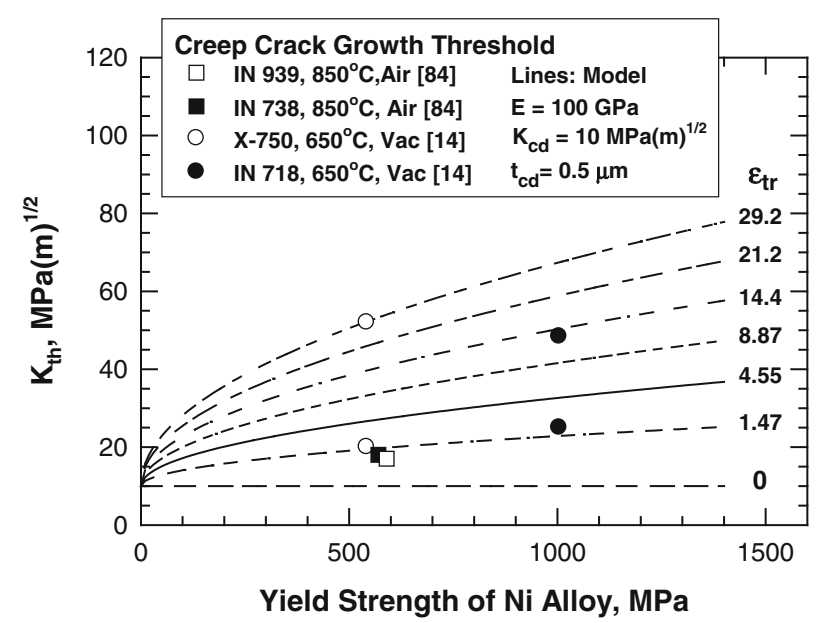

Fig. 8-Predicted and measured $K_{\text {th }}$ values for creep crack growth by grain boundary cavitation in Alloy 718, IN 738, IN 939, and $\mathrm{X}-750$. Experimental data are taken from the literature. ${ }^{[14,84]}$

the same time increases the $K_{\text {th }}$ for the onset of oxidation-induced crack growth. The range of the predicted $K_{\text {th }}$ values for Ni-based alloys is in agreement with those observed in Ni-based alloys tested in air was well as those observed in IN 718 and a modified IN 100 tested in pure oxygen. ${ }^{[8,9,19]}$ In the latter two cases, the $K_{\text {th }}$ values are about $20-28 \mathrm{MPa}(\mathrm{m})^{1 / 2}$ at $873 \mathrm{~K}$ to $973 \mathrm{~K}\left(600{ }^{\circ} \mathrm{C}\right.$ to $\left.700{ }^{\circ} \mathrm{C}\right)$ in pure oxygen, ${ }^{[8,9,19]}$ similar to those shown in Figures 5 and 6 for the air environment. Above the $K_{\text {th }}$, the crack growth kinetics are enhanced by the oxygen environment, similar to those observed in air, when the crack extends past the transformation toughened zone where compressive 


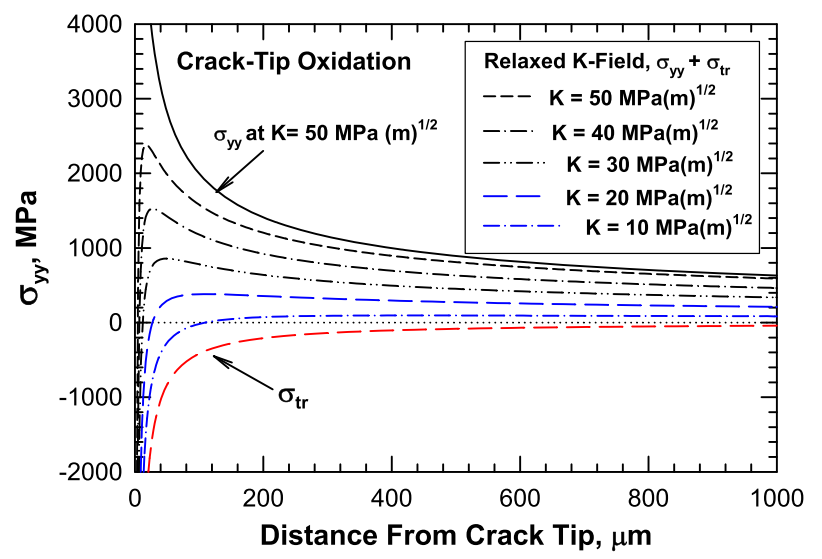

Fig. 9 - Computed stress distributions of the relaxed stress field $\left(\sigma_{y y}+\sigma_{\mathrm{tr}}\right)$ at various $K$ levels compared to the K-field at $K=50 \mathrm{MPa}(\mathrm{m})^{1 / 2}$ and the transformation stresses, $\sigma_{\mathrm{tr}}$. A tensile stress peak develops ahead of the crack tip, but the near-tip zone size where compressive stresses are dominant at the crack tip decreases with increasing $K$ levels at $K>20 \mathrm{MPa}(\mathrm{m})^{1 / 2}$.

stresses are dominant. Further ahead of the crack tip, a high tensile stress peak exists which can cause fracture of any oxide layer formed and hence leads to enhanced crack growth rates. Another important prediction that can be made from the results shown in Figure 9 is that fracture of the oxide layer is size-dependent. Fracture of a short oxide layer is expected to be more difficult when it is embedded entirely within the compressive stress zone. In contrast, fracture of a long oxide layer is expected to be easier when the oxide layer lies mostly outside the compressive stress zone and is acted upon by the tensile stress peak.

The dependence of the transformation strain on the reactants provides additional insights on the roles of microstructure on oxidation-induced time-dependent crack growth. The transformation strain, as defined by Eq. [6], is generally different from the Pilling-Bedworth $(\mathrm{P}-\mathrm{B})$ ratio, ${ }^{[87]}$ which is the ratio of the volume of the unit cell of the oxide to the volume of the unit cell of the corresponding metal from which the oxide is created (i.e., $\mathrm{P}-\mathrm{B}$ ratio $\left.=V_{\mathrm{ox}} / V_{\mathrm{o}}\right)$. However, the transformation strain, Eq. [8], is related to the $\mathrm{P}-\mathrm{B}$ ratio $\left(\varepsilon_{\mathrm{tr}}=\mathrm{P}-\mathrm{B}\right.$ ratio -1$)$ when the reactant is a pure metal. In general, Ni-based superalloys contain $\gamma^{\prime}$ in a $\gamma$ matrix (Ni solid solution) with a number of minor phases, such as carbides ( $\left.\mathrm{MC}, \mathrm{M}_{23} \mathrm{C}_{6}, \mathrm{M}_{6} \mathrm{C}\right)$, borides $\left(\mathrm{M}_{2} \mathrm{~B}_{2}\right)$ and intermetallic phases (sigma, $\mu, \delta$ and $\gamma^{\prime \prime}$ ), depending on the alloy composition and heat-treatment. ${ }^{[88]}$ Some Ni-based superalloys do not contain certain carbides or phases; for example, IN 718 does not contain $\mathrm{M}_{23} \mathrm{C}_{6}$ due to a high Ti content and a high $\mathrm{Nb}$ content. The discussion on the effects of reactant on $K_{\mathrm{th}}$, therefore, is directed to Nibased alloys in general and is not directed to a specific alloy. Should a particular phase not exist in a particular alloy (e.g., $\mathrm{M}_{23} \mathrm{C}_{6}$ does not exist in IN $718^{[88]}$ ), the predicted effect of the reactant (for example, $\mathrm{M}_{23} \mathrm{C}_{6}$ ) would obviously not occur and be replaced by one that is known to exist (e.g., $\mathrm{NbC}$ in IN $718^{[88]}$ ) in the alloy of interest. A full range of reactants is considered so that their relative importance can be assessed in a systematic manner for Ni-based superalloys with various compositions. First, oxidation of metallic carbides such as $\mathrm{M}_{23} \mathrm{C}_{6}$ or $\mathrm{NbC}$ would lower the $K_{\text {th }}$ and leads to accelerated $d a /$ $d t$, because the transformation stresses induced at the crack tip are tensile rather than compressive (see Table III). Formation of $\mathrm{Nb}_{2} \mathrm{O}_{5}$ also does not provide any transformation toughening, as shown in Table III. Thus, grain boundary $\mathrm{M}_{23} \mathrm{C}_{6}$ and $\mathrm{NbC}$ should be avoided based on consideration of the $K_{\mathrm{th}}$ level. Second, $K_{\text {th }}$ is enhanced with increasing yield strength of the $\mathrm{Ni}$ alloy. Thus, any microstructure or alloying modification that enhances yield strength of the alloy would also improve the $K_{\mathrm{th}}$ value, as reported in the literature. ${ }^{[41]} \mathrm{It}$ has been reported that the dwell fatigue performance of Ni-base superalloys can be improved by increasing $\mathrm{Cr}$ content, ${ }^{[89,90]}$ volume fraction of $\gamma^{\prime},{ }^{[89]}$ and the size of tertiary $\gamma^{\prime}$ precipitates. ${ }^{[41,91,92]}$ The improvements by increasing $\mathrm{Cr}$ content and tertiary $\gamma^{\prime}$ size are qualitatively illustrated in Figure 10(a). One possible explanation for these microstructural and alloying effects may be the increase in transformation toughening and the $K_{\text {th }}$ value by increasing $\mathrm{Cr}$ contents on the basis that increasing the $\mathrm{Cr}$ content of the Ni-base alloy is likely to promote the formation of $\mathrm{Cr}_{2} \mathrm{O}_{3}$. Similarly, increasing the tertiary $\gamma^{\prime}$ size is likely to promote stress relaxation at the cracktip,${ }^{[91,92]}$ which would delay fracture of the oxide and increase the apparent $K_{\mathrm{th}}$. In addition, the larger tertiary $\gamma^{\prime}$ size may also promote the formation of $\mathrm{Al}_{2} \mathrm{O}_{3}$ by $\mathrm{Al}$ from tertiary $\mathrm{Ni}_{3} \mathrm{Al}$ at or near grain boundaries. The transformation stresses associated with the mixed $\mathrm{Cr}_{2} \mathrm{O}_{3}$ and $\mathrm{Al}_{2} \mathrm{O}_{3}$ formation at the crack tip can cause additional crack-tip shielding, lower the near-tip stress intensity factor $\left(K_{\text {tip }}\right)$, leading to increases in the $K_{\text {th }}$ and lowering of the $d a / d t$ rates as shown schematically in Figure 10(b). Since the fatigue crack growth rate during dwell fatigue is given by Eq. [2], which consists of a cycledependent crack growth term, $d a / d N$, and a timedependent crack growth term, $d a / d t$. Increasing the $K_{\text {th }}$ values can reduce $d a / d t$ to lower values or even zero and improve the dwell fatigue crack growth resistance as shown in Figure 10(b). It should also be noted that above $K_{\mathrm{th}}, d a / d t$ decreases with increasing grain size $\mathrm{e}^{[23,90,93]}$ as the time-dependent crack growth process is generally controlled by grain boundary diffusion. ${ }^{[3,6,23]}$ Furthermore, the grain boundary structure and character can affect the $d a / d t$ response in several ways, including (1) serrated grain boundary can hinder grain boundary sliding ${ }^{[94,95]}$ and reduce stress concentration at the grain boundary, thereby delaying fracture of the oxide layer and improving crack growth resistance, (2) the type of reactants (e.g., carbides or Laves Phase) ${ }^{[88]}$ may vary with the grain boundary character, thereby affecting the type of oxide(s) formed along the crack-tip grain boundary, and (3) the transport of oxygen vacan$\operatorname{cies}^{[96]}$ to the tip of the oxide layer along the oxide/grain boundary interface or through the oxide layer under the influence of the crack-tip stress field. ${ }^{[86,97]}$

The results of this study suggest that one possible means of suppressing time-dependent crack growth is to increase the $K_{\text {th }}$ values as high as possible. For the oxides investigated, the most promising oxides are $\mathrm{Cr}_{2} \mathrm{O}_{3}$ and $\mathrm{Al}_{2} \mathrm{O}_{3}$, which are both protective oxides. 




(a)

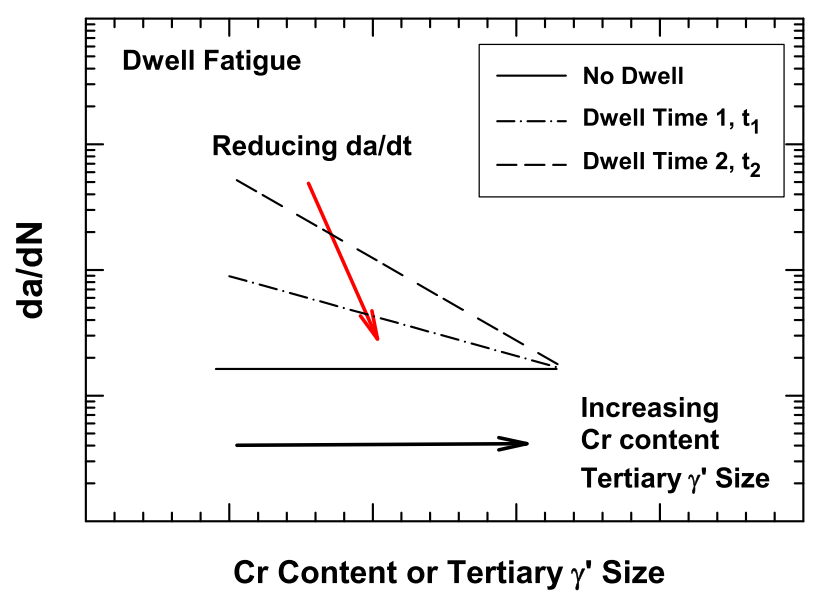

(b)

Fig. 10-Schematics depicting the effects of Cr content and tertiary $\gamma^{\prime}$ size on $d a / d t$ and $d a / d N$ response during dwell fatigue crack growth: (a) $d a / d t$ response, and (b) $d a / d N$ response during dwell fatigue.

Assuming a mixture of $\mathrm{Cr}_{2} \mathrm{O}_{3}$ and $\mathrm{Al}_{2} \mathrm{O}_{3}$ oxide formation at the crack tip, the computed $K_{\text {th }}$ values range from 25 to $34 \mathrm{MPa}(\mathrm{m})^{1 / 2}$ based on yield strength of $1000 \mathrm{MPa}$, as shown in Figure 11 . These $K_{\text {th }}$ values are higher than those expected based on a mixture of $\mathrm{NiO}$ and $\mathrm{Cr}_{2} \mathrm{O}_{3}$ or a mixture of $\mathrm{CrO}$ and $\mathrm{Al}_{2} \mathrm{O}_{3}$. An oxide layer of 100 pet $\mathrm{Al}_{2} \mathrm{O}_{3}$ provides a $K_{\text {th }}$ value of $34 \mathrm{MPa}(\mathrm{m})^{1 / 2}$ at yield strength of $1000 \mathrm{MPa}$. All of these $K_{\text {th }}$ values are based on a layer thickness of $0.25 \mu \mathrm{m}$, which are on the order of the thickness of crack-tip oxide layers reported in the literature. ${ }^{[28]}$

The approach adopted in this investigation to combine cycle-dependent and time-dependent crack growth is through the summation law as described in Eqs. [1] and [2]. This is not a new approach but has been utilized successfully by others ${ }^{[19,20]}$ to treat combined cycledependent and time-dependent crack growth in structural alloys. The implicit assumption of this approach is that there are no interactions between the cycle-dependent (i.e., fatigue) crack growth mechanism due to cyclic slip in the plastic zone and the time-dependent crack growth mechanism due to oxide formation at the crack tip and fracture of the oxide layer. The summation law shown in



Fig. 11-Predicted $K_{\text {th }}$ values as a function of volume fraction of oxide $\mathrm{B}$ associated with the formation of mixed oxides $\mathrm{A}$ and $\mathrm{B}$ at the crack tip.

Eq. [1] is simple and particularly useful for life-prediction of structural components, since it is applicable for arbitrary loading and temperature histories in a mission profile as one merely needs to integrate Eq. [1] over the mission profile in order to obtain the fatigue life of a structural component. This approach has been successfully applied to assess the fatigue life and reliability of the engine components subjected to mission profiles that contain hot dwell conditions ${ }^{[20,21,23]}$ or hot corrosion environments. ${ }^{[98]}$ Both the frequency and hold-time effects during dwell fatigue have been predicted for two Ni-based superalloys used in turbo-engine component applications. ${ }^{[23,98]}$ In contrast, the approach based on Eqs. [1] and [2] has not been applied by the author to treat corrosion fatigue where the crack growth process may be dictated by the rate of rupture of the protective oxide film relative to the rate of passive film formation. Thus, the applicability of the summation law to corrosion fatigue is incomplete and an open issue that requires further studies.

\section{CONCLUSIONS}

The conclusions reached in this investigation are as follows:

1. A micromechanical modeling framework has been developed for predicting the $K_{\text {th }}$ values and their variability for oxidation-induced crack growth, creep crack growth, and stress corrosion cracking in Ni-base superalloys.

2. Compressive stresses associated with the formation of oxides or creep cavities at the crack tip with a positive transformation strain can instigate transformation toughening by relaxing and shielding of the crack-tip tensile stresses and induce a growth threshold that must be exceeded in order for the onset of time-dependent crack growth.

3. Oxide formation that can instigate a time-dependent crack growth threshold includes those of $\mathrm{NiO}, \mathrm{CrO}$, $\mathrm{CoO}, \mathrm{FeO}, \mathrm{Cr}_{2} \mathrm{O}_{3}, \mathrm{Al}_{2} \mathrm{O}_{3}$, and $\mathrm{Fe}_{2} \mathrm{O}_{3}$. 
4. Oxidation of $\mathrm{NbC}$ at grain boundaries and the formation of $\mathrm{Nb}_{2} \mathrm{O}_{5}$ induce tensile stress, crack-tip anti-shielding, and oxidation-induced embrittlement.

5. The dichotomy of high growth thresholds and enhanced crack growth rates associated with timedependent crack growth in Ni-base alloys may be explained on the basis of transformation toughening that induces compressive stresses at the crack tip which are dominant at low $\mathrm{K}$ levels and diminish with increasing $\mathrm{K}$ levels.

6. The variability of $K_{\mathrm{th}}$ in Ni-base superalloys appears to originate from mixed oxides formation at the crack tip.

7. Material parameters that contribute to a high $K_{\text {th }}$ include high Young's modulus of oxide, high transformation strain, and high yield strength of the Ni-base alloys.

8. Time-dependent crack growth in Ni-base alloys may be suppressed by instigating a high $K_{\text {th }}$ value through a high transformation strain, a high chromium content, and high yield strength.

\section{ACKNOWLEDGMENTS}

This work was supported by NAVAIR under contract No. N68335-13-C-0101 and monitored by Mr. Raymond A. Pickering. The authors are thankful for the support of Pratt \& Whitney in providing the IN 718 data used in this study. The assistance by Ms. Lori Salas, SwRI, in the preparation of the manuscript is acknowledged.

\section{REFERENCES}

1. K. Sadananda and P. Shahinian: in Micro and Macro Mechanics of Crack Growth, K. Sadananda, B.B. Rath, and D.J. Michel, eds., Metallurgical Society of AIME, Warrendale, PA, 1981, pp. 11930.

2. J.P. Pedron and A. Pineau: Mater. Sci. Eng., 1982, vol. 56, pp. $143-56$

3. S. Floreen and R. Raj: Flow and Fracture at Elevated Temperature, Warrendale, PA, ASM, 1983, pp. 383-404.

4. A. Diboine and A. Pineau: Fatigue Fract. Eng. Mater. Struct., 1987, vol. 10, pp. 141-51.

5. E. Andrieu, R. Cozar, and A. Pineau: in Superalloys Metallurgy \& Applications, E.A. Loria, ed., ASM, Pittsburgh, PA, 1989, pp. $241-47$

6. D.A. Woodford: Energy Mater., 2006, vol. 1 (1), pp. 59-79.

7. R. Molins, J.-C. Chassaigne, and E. Andrieu: in Superalloys Various Derivatives, E.A. Loria, ed., TMS, Warrendale, PA, 1997, pp. 655-64.

8. M. Gao, D.J. Dwyer, and R.P. Wei: in Superalloys 718, 625, 706 and Various Derivatives, E.A. Loria, ed., TMS, 1994, pp. 581-92.

9. R.P. Wei and Z. Huang: Mater. Sci. Eng., 2002, vol. A336, pp. 209-14.

10. K.S.Chan, M.P. Enright, and J.P. Moody: ASME Turbo Expos 2013, Paper GT 2013-95057, San Antonio, TX, 3-7 June 2013.

11. A. Arioka, T. Yamada, T. Migamoto, and T. Terachi: Corrosion, 2011, vol. 67 (3), pp. 035006-1-035006-18.

12. S. Floreen: Metall. Trans. A, 1975, vol. 17A, pp. 1741-49.

13. S. Floreen: in Fatigue, Environment and Temperature Effects, J.J. Burke and V. Weiss, ed., Plenum Press, New York, 1983, pp. 145-62.
14. K. Sadananda and P. Shahinian: Mater. Sci. Eng., 1982, vol. 43, pp. 159-68.

15. K. Sadananda and P. Shahinian: in Creep-Fatigue Environment Interactions, R.M. Pelloux and N.S. Stoloff, eds., TMS-AIME, 1979, pp. 86-111.

16. K. Sadananda and P. Shahinian: J. Eng. Mater. Technol., 1978, vol. 100 , pp. $381-87$.

17. K. Sadananda and P. Shahinian: Metall. Trans. A, 1983, vol. 16A, pp. $1467-80$.

18. P. Shahinian and K. Sadananda: J. Eng. Mater. Technol., 1979, vol. 101, pp. 225-30.

19. R.P. Wei and J.D. Landes: Mater. Res. Stand., 1969, vol. 44 (46), pp. $25-27$

20. R.H. Van Stone and D.C. Slavik: Fatigue and Fracture Mechanics: 31st Volume, ASTM STP 1389, G.R. Halford and J.P. Gallagher, eds., ASTM, West Conshohocken, PA, 2000, pp. 405-26.

21. K.S. Chan, M.P. Enright, J.P. Moody, B. Hocking, and S.H.K. Fitch: J. Eng. Gas Turbine Power, 2012, vol. 134, p. 122501.

22. P.C. Paris and F. Erdogan: Trans. ASME J. Basic Eng. Ser. D, 1963, vol. 85 (3), pp. 528-34.

23. K.S. Chan, M.P. Enright, J.P. Moody, and S.H.K. Fitch: Metall. Mater. Trans. A, 2013, DOI:10.1007/S11661-013-1971-9 (published on line).

24. W. Hoffelner: Mater. Sci. Technol., 1987, vol. 3, pp. 765-70.

25. M.Y. Nazmy and S. Wuthrich: Mater. Sci. Eng., 1983, vol. 61, pp. 119-25.

26. P. Valerio, M. Gao, and R.P. Wei: Scripta Metall. Mater., 1994, vol. 30 , pp. $1269-74$

27. T. Connolley, M.J. Starink, and P.A.S. Reed: in Superalloys 2000, T.M. Pollock, R.D. Kissinger, R.R. Bowman, K.A. Green, M. McLean, S. Olson, and J.J. Schirra, eds., TMS, Warrendale, PA, 2000, pp. 435-44.

28. D.M. Knowles and D.W. Hunt: Metall. Mater. Trans. A, 2002, vol. $33 \mathrm{~A}$, pp. 3165-72.

29. T.P. Gabb, J. Telesman, P.T. Kantzos, J.W. Smith, and P.F. Browning: in Superalloys 2004, K.A. Green, T.M. Pollock, H. Harada, T.E. Howson, R.C. Reed, J.J. Schirra, and S. Walston, eds., TMS, Warrendale, PA, 2004, pp. 269-74.

30. M. Olszta, D. Schreiber, L. Thomas, and S. Bruemmer: $A d v$. Mater. Process., 2012, vol. 170 (4), pp. 17-21.

31. J. Panter, B. Viguier, J.-M. Cloue, M. Foucault, P. Combrade, and E. Andrieu: J. Nucl. Mater., 2006, vol. 348, pp. 213-21.

32. G.C. Sih: Int. J. Fract. Mech., 1966, vol. 2, pp. 628-31.

33. D. Broek: Elementary Engineering Fracture Mechanics, Sijthoff \& Noordhoff, Alphen aan den Riju, 1978, pp. 70-71.

34. J.D. Eshelby: Proc. R. Soc., 1957, vol. A241, pp. 376-96.

35. S.-Q. Shi and M.P. Puls: J. Nucl. Mater., 1994, vol. 208, pp. 232 42.

36. R.M. McMeeking and A.G. Evans: J. Am. Ceram. Soc., 1982, vol. 65 , pp. $242-46$.

37. B. Budiansky, J.C. Amazigo, and A.G. Evans: J. Mech. Phys. Solids, 1988, vol. 26, pp. 167-87.

38. R.J. Dimelfi and W.D. Nix: Int. J. Fract., 1977, vol. 13, pp. 34148.

39. D.A. Miller and R. Pilkington: Metall. Trans. A, 1980, vol. 11A, pp. $177-80$.

40. P. Hancock: in Vacancies '76, R.E. Smallman and J.E. Harris, eds., The Metals Society, London, 1976, pp. 215-22.

41. J. Telesman, P. Kantzos, J. Gayda, P.J. Bonacuse, and A. Prescenzi: in Superalloys 2004, K.A. Green, T.M. Pollock, H. Harada, T.E. Howson, R.C. Reed, J.J. Schirra, and S. Walston, eds., TMS, Warrendale, PA, 2004, pp. 215-24.

42. I.P. Vasatis and R.M. Pelloux: Metall. Trans. A, 1985, vol. 16A, pp. $1515-20$

43. R.M. Pelloux and J.S. Huang: Creep-Fatigue Environment Interactions, R.M. Pelloux and N.S. Stoloff, eds., The Metallurgical Society of AIME, New York, 1980

44. K.R. Bain and R.M. Pelloux: in 5th International Symposium on Superalloys, M. Gell, C.S. Kortovich, R.H. Bricknell, W.B. Kent, and J.F. Radavich, eds., Metallurgical Society of AIME, Warrendale, PA, 1984.

45. J. Tsang, R.M. Kearsey, P. Au, S. Oppenheimer, and E. McDevitt: Can. Metall. Q., 2011, vol. 50 (3), pp. 222-31.

46. M.Y. Nazmy and C. Würthrich: Mater. Sci. Eng., 1983, vol. 61, pp. 119-25. 
47. J.R. Groh and D.P.Mourer: in Superalloys 2004, K. A. Green, T.M. Pollock, H. Harada, T.E. Howson, R.C. Reed, J.J. Schirra, and S. Walston, eds., TMS, Warrendale, PA, 2004, pp. 101-08.

48. R. Cozar and A. Pineay: Metall. Trans., 1973, vol. 4, pp. 47-59.

49. K. Kusabiraki, H. Komatsu, and S. Ikeuchi: Metall. Mater. Trans. A, 1998, vol. 29A, pp. 1169-74.

50. J.C. Zhao, V. Ravikumar, and A.M. Beltran: Metall. Mater. Trans. A, 2001, vol. 32A, pp. 1271-82.

51. T. Sourmail: Mater. Sci. Technol., 2001, vol. 17, pp. 1-14.

52. T.M. Pollock and S. Tin: J. Propuls. Power, 2006, vol. 22, pp. 361-74.

53. J. Laigo, F. Tancret, R. Le Gall, and J. Furtado: Adv. Mater. Res., 2007, vols. 15-17, pp. 702-07.

54. W. Acchar and C.A. Cairo: Mater. Res., 2006, vol. 9, pp. 171-74.

55. K. Koji, N. Yokotani, and Y. Umakoshi: Mater. Sci. Forum, 2006, vol. 512, pp. 67-72.

56. K. Hirota, K. Mitani, M. Yoshinak, and O. Yamaguchi: Mater. Sci. Eng. A, 2005, vol. 399, pp. 154-60.

57. G.A. Young, T.E. Capobianco, M.A. Penik, B.W. Morris, and J.J. McGee: Weld. J., 2008, vol. 87, pp. 31s-43s.

58. J.D. Rigney and J.J. Lewandowski: Mater. Sci. Eng. A, 1992, vol. 149, pp. 143-51.

59. W.W. Gerberich, W.M. Mook, C.B. Carter, and R. Ballarini: Int. J. Fract., 2007, vol. 148, pp. 109-15.

60. S. Musikant: What Every Engineer Should Know About Ceramics, Marcel Dekker, Inc., 1991, pp. 102-05.

61. T. Chudoba, N. Schwarzer, and F. Richter: Surf. Coat. Technol., 2000, vol. 127, pp. 9-17.

62. D. Tromans and J.A. Meech: Miner. Eng., 2002, vol. 15, pp. 1027 41.

63. J.A. Crawford: J. Appl. Phys., 1964, vol. 35, pp. 2413-18.

64. P. Thompson, D.E. Cox, and J.B. Hastings: J. Appl. Crystallogr., 1987, vol. 20, pp. 79-83.

65. H. Berger, H. Tang, and F. Levy: J. Cryst. Growth, 1993, vol. 130, pp. $108-12$.

66. C. Yan and D. Yue: Adv. Mater., 2008, vol. 20, pp. 1055-58.

67. D.R. Lide: CRC Handbook of Chemistry and Physics, 79th ed., CRC, Boca Raton, FL, 1998/1999.

68. T. Bredow and A.R. Gerson: Phys. Rev. B., 2000, vol. 61, pp. 5194-201.

69. X.S. Du, S. Hak, T. Hibma, O.C. Rogojanu, and B. Struth: J. Cryst. Growth, 2006, vol. 293, pp. 228-32.

70. R. Guillament, J. Lopitaux, B. Hannoyer, and M. Lenglet: J. Phys. IV Colloque C9, 1993, vol. 3, pp. 349-56.

71. R.W. Hertzberg: Deformation and Fracture Mechanics of Engineering Materials, Wiley, New York, 1976, p. 8.

72. W.-B. Zhang, Y.-H. Deng, Y-L. Hu, K-L Han, and B-Y. Tang: Science Direct, Solid State Communications, vol. 142, 2007, pp. 6-9.

73. S.K. Sahoo, K. Agarwal, A.K. Singh, B.G. Polke, and K.C. Raha: Int. J. Eng. Sci. Technol., 2010, vol. 2 (8), pp. 118-26.

74. M. Krzyzanowski. J.H. Beynon, and D.C.J. Farrugia: Technology and Engineering, VHC Wiley Verlag, Weinheim, 2010, p. 174.

75. T. Amano, M. Okazaki, T. Takezawa, A. Shiino, M. Takeda, T. Onishi, K. Seto, A. Ohkubo, and T. Shishido: Mater. Sci. Forum, 2006, vols. 522-523, pp. 469-76.

76. T.P. Gabb, J. Telesman, B. Hazel, and D.P. Mourer: J. Mater. Eng. Perform., 2010, vol. 19 (1), pp. 77-89.
77. Material data provided through direct telecommunications and in Probabilistic Design for Rotor Integrity (PDRI) Interim Report 9, Southwest Research Institute, March 4, 2010. The tests were performed by PWA and funded under FAA Grant 05-G-005.

78. R.H. Van Stone, P.G. Gooden and D.D. Krueger: Final Report, AFWAL-TR-88-4146, Wright-Patterson Air Force Base, OH, 1988.

79. T. Nicholas and T. Weerassoriya: in Fracture Mechanics ASTM STP 905, J.H. Underwood, R. Chait, C.W. Smith, D.P. Wilhem, W.R. Andrews, and J.C. Newman, eds., American Society for Testing and Materials, Philadelphia, p. 155.

80. S.S. Kim, S.J. Choe, and K.S. Shin: Met. Mater., 1998, vol. 4 (1), pp. 15-23.

81. C.D. Liu, Y.F. Han, M.G. Yan, and M.C. Charturved: in Superalloys 178, 625 and Various Derivatives, E.A. Loria, ed., TMS, Warrendale, PA 1991, pp. 537-548.

82. K.R. Bain and R.M. Pelloux: Metall. Trans. A, 1984, vol. 15A, pp. 381-88.

83. J. Gayda, T.P. Gabb, and T.V. Miner: Low Cycle Fatigue, ASTM STP 942, H.D. Solomon, G.R. Halford, L.R. Kaisand, and B.N. Leis, eds., American Society for Testing and Materials, Philadelphia, PA, 1988, pp. 293-309.

84. W. Hoffelner: Metall. Trans. A, 1982, vol. 13A, pp. 1245-55.

85. W. Carpenter, B.D.-J. Kang, and K.M. Chang: Superalloys 718 , 625, 706 and Various Derivatives, E.A. Loria, ed., TMS, Warrendale, PA, 1997, pp. 579-688.

86. H.E. Evans, H.Y. Li, and P. Bowen: Scripta Mater., 2013, vol. 69, pp. $179-82$.

87. N.B. Pilling and R.E. Bedworth: J. Int. Met., 1923, vol. 29, pp. 539-91.

88. H.E. Collins: Proceedings of the International Symposium on Structural Stability in Superalloys, M.J. Donachie, ed., TMS, Warrendale, PA, 1968, pp. 171-98.

89. K.-M. Chang, M.F. Henry, and M.G. Benz: JOM, 1990, vol. 42 (12), pp. 29-35.

90. K.-M. Chang: in Superalloys 718, 625 and Various Derivatives, E.A. Loria, ed., TMS, Warrendale, PA, 1991, pp. 447-56.

91. T.P. Gabb, J. Gayda, J. Telesman, and A. Garg: in Superalloy 2008, R.C. Reed, K.A. Green, P. Caron, T.P. Gabb, M.G. Farhmann, E.S. Huron, and S.A. Woodard, eds., TMS, Warrendale, PA, 2008, pp. 121-30.

92. J. Telesman, T.P. Gabb, A. Garg, P. Bonacuse, and J. Gayda: in Superalloy 2008, R.C. Reed, K.A. Green, P. Caron, T.P. Gabb, M.G. Farhmann, E.S. Huron, and S.A. Woodard, eds., TMS, Warrendale, PA, 2008, pp. 807-16.

93. J.M. Larson and S. Foreen: Metall. Trans. A, 1977, vol. 8A, pp. $51-55$.

94. H.J. Wu and A.K. Kowl: Adv. Perform. Mater., 1997, vol. 4, pp. 409-20.

95. S. Xu, X.-J. Wu, A.K. Koul, and J.I. Dickson: Metall. Mater. Trans. A, 1999, vol. 30A, pp. 1039-45.

96. G.J. Koel and P.J. Gellings: Oxid. Met., 1972, vol. 5, pp. 185-203.

97. J. Kitaguchi, H.T. Li, H.E. Evans, R.G. Ding, I.P. Jones, G. Baxter, and P. Bowen: Acta Mater., 2013, vol. 61, pp. 1968-81.

98. K.S. Chan, M.P. Enright, and J.P. Moody: J. Eng. Gas Turbines Power, 2014, vol. 136 (22502), pp. 1-8. 